\title{
Review of species of the genus Chrysoplatycerus Ashmead, 1889 (Hymenoptera: Encyrtidae)
}

\author{
Обзор видов рода Chrysoplatycerus Ashmead, 1889 \\ (Hymenoptera: Encyrtidae)
}

\author{
V.A. Trjapitzin ${ }^{1}$, S.V. Triapitsyn ${ }^{2}$ \\ B.A. Тряпиџын ${ }^{1}$, C.В. Тряпиџын ${ }^{2}$
}

\footnotetext{
${ }^{1}$ Do vostrebovania, Post Office 129344 (7 ulitsa Letchika Babushkina), Moscow, Russia.

${ }^{2}$ Entomology Research Museum, Department of Entomology, University of California, Riverside, California 92521, USA. E-mail: serguei.triapitsyn@ucr.edu

1 До востребования, п/о 129344 (ул. Летчика Бабушкина, д. 7), Москва, Россия.

2 Энтомологический музей, Отделение энтомологии, Университет штата Калифорния, Риверсайд, Калифорния 92521, США.
}

KEY WORDS: Hymenoptera, Encyrtidae, Chrysoplatycerus, taxonomy, key, parasitoid, Pseudococcidae, biocontrol.

КЛЮЧЕВЫЕ СЛОВА: Нуmenoptera, Encyrtidae, Chrysoplatycerus, таксономия, определительная таблица, паразитоид, Рseudococcidae, биометод.

ABSTRACT. A diagnosis of the genus Chrysoplatycerus Ashmead (Hymenoptera: Encyrtidae), a key to its six known species, and their synopsis are given, with special attention to the economically important species Ch. splendens (Howard, 1888). All known members of this genus are parasitoids of mealybugs (Homoptera: Pseudococcidae) and of the New World origin, and only Ch. splendens was successfully introduced into the Republic of South Africa and also has penetrated recently into Italy. Ch. howardii Ashmead, 1900 , stat.rev., for which a lectotype is designated, is treated provisionally as a valid species rather than a synonym of $C h$. splendens.

РЕЗЮМЕ. В статье приводятся диагноз рода Chrysoplatycerus Ashmead, 1889 (Hymenoptera: Encyrtidae) и определительная таблица шести его известных видов, а также дан обзор видов, причем особое внимание уделяется экономически важному Ch. splendens (Howard, 1888). Все известные виды этого рода являются паразитоидами мучнистых червецов (Homoptera: Pseudococcidae) и родом из Западного Полушария. Только Ch. splendens был успешно интродуцирован в Южно-Африканскую Республику и недавно проник в Италию. Ch. howardii Ashmead, 1900, stat.rev., для которого обозначен лектотип, условно трактуется как валидный вид, а не как синоним Ch. splendens.

\section{Introduction}

This contribution was prompted by the discovery in Italy of an accidentally introduced encyrtid species Chrysoplatycerus splendens (Howard, 1888). This par- asitoid was reared there from the Comstock mealybug Pseudococcus comstocki (Kuwana, 1902) (Homoptera: Pseudococcidae), a pest of many cultivated plants [Guerrieri, Pellizzari, 2009]. The genus Chrysoplatycerus Ashmead, 1889, of the New World origin, was not included into the monograph on the Palaearctic Encyrtidae by Trjapitzin [1989]. Its species are primary parasitoids of mealybugs on citrus (Citrus spp.), cultivated grape (Vitis vinifera Linnaeus, 1753), pear (Pyrus communis Linnaeus, 1753), and other agricultural and ornamental trees, shrubs, and lianas. They are of potential importance to the classical biological control and integrated pest management programs against their mealybug hosts.

This paper is dedicated to Alexandr P. Rasnitsyn, an outstanding researcher of fossil and extant Hymenoptera.

Acronyms of the depositories of the specimens are as follows: ANSP — The Academy of Natural Sciences, Philadelphia, Pennsylvania, USA; EMEC — Essig Museum, University of California, Berkeley, California, USA; FSCA The Museum of Entomology, Florida State Collection of Arthropods, Gainesville, Florida, USA; UCRC - Entomology Research Museum, University of California, Riverside, California, USA; USNM - National Museum of Natural History, Washington, USA; ZIN - Zoological Institute, Russian Academy of Sciences, St. Petersburg, Russia. An abbreviation used in the text is: F - an antennal funicular segment.

\section{Genus Chrysoplatycerus Ashmead, 1889}

Rileya Howard in Smith, 1888: 80 [July]; Howard, 1888: 191; Ashmead, 1888: 230; Howard, 1889: 14. Type species: Rileya splendens Howard, 1888, by monotypy. Generic name preoccupied by Rileya Ashmead, 1888 (Eurytomidae) [June]. 
Chrysoplatycerus Ashmead, 1889: 38. Type species: Rileya splendens Howard, 1888, by monotypy. Replacement name for Rileya Howard, 1888. Subsequent references: Timberlake, 1922 1; Peck, 1963: 448; Kerrich, 1978: 113, 136; Singh, 1995: 161, 165, 171; Noyes, 2000: 214 (Chrysoplatycerus Howard [sic!])

Encyrtolophus De Santis, 1972: 49. Type species: Encyrtolophus flavicollis De Santis, 1972, by original designation. (Synonymized by Kerrich, 1978: 136).

Paraplatycerus Hall, 1974: 19. Type species: Paraplatycerus citriculus Hall, 1974, by original designation. (Synonymized by Kerrich, 1978: 136).

Metaplatycerus Gordh and Trjapitzin in Trjapitzin and Gordh, 1978: 384. Type species: Chrysoplatycerus ferrisi Timberlake, 1922, by original designation. (Synonymized by Noyes, 1980: 185). Subsequent reference: Gordh and Trjapitzin, 1979: 105.

DIAGNOSIS. Female. Body compact, not flattened. Head hypognathous. Frontovertex narrow. Facial scrobes delimited dorsally and laterally by a sharp frontofacial ridge. Antennal scape strongly broadened and flattened, with flat or slightly concave dorsal margin; flagellum more or less broadened and flattened; pedicel subtriangular, its dorsal margin usually similar to that of scape; funicle 6-segmented, with all segments strongly transverse; clava 2-segmented, obliquely truncate at apex. Mandible with three acute teeth, middle tooth the longest. Palpal formula $4-3$. Pronotum short. Mesoscutum without notauli (parapsidal furrows). Scutellum flat or convex, either with or without a tuft of long hairs at apex, and sometimes with a median longitudinal keel. Wings not abbreviated; fore wing infuscate except with a hyaline basal third devoid of discal pubescence; linea calva complete and open posteriorly, with a group of more or less flattened scalelike hairs along its posterior margin; filum spinosum absent. Marginal vein of fore wing punctiform; stigmal vein usually curved towards wing margin; postmarginal vein as long as stigmal vein or somewhat shorter. Hypopygium (= VII abdominal or fifth gastral sternite) reaching apex of gaster; paratergites present. Ovipositor sheaths not exserted. Body length 1.1-2.4 mm.

Male. Frontovertex broad. Scape of antenna almost linear or slightly broadened ventrally; pedicel small or very short; flagellum broader than scape and with short hairs and numerous linear sensilla, funicular segments wider than long or subquadrate to a little longer than wide; clava entire, not broader than funicle. Fore wing hyaline; marginal vein a little longer than wide, stigmal vein straight, postmarginal vein notably longer than stigmal vein (unlike in female). Body length 0.84-1.29 $\mathrm{mm}$.

BIOLOGY. Primary endoparasitoids of mealybugs (Pseudococcidae).

DISTRIBUTION. The native range of Chrysoplatycerus species is the American Continent and the Carribean Islands. Ch. splendens penetrated together with its host(s) into Bermuda (UK), the Hawaiian Islands (USA), and Italy, and was intentionally and successfully introduced into the Republic of South Africa where it became established [Joubert, 1943].

REMARK. Parapsidal furrows are called "notauli" in the recent English literature on Chalcidoidea [Gibson, 1997]. These are called "parapsidal furrows (or lines)" in the Russian literature on Encyrtidae (and thus have been often incorrectly translated) although the structure may be or may be not homologous to the notauli of other chalcidoids and thus may not have a proper name at present.

SYSTEMATIC POSITION. The genus Chrysoplatycerus was placed in the subtribe Chrysoplatycerina Trjapitzin, 1968 of the tribe Chrysoplatycerini Trjapitzin, 1968 of the subfamily Tetracneminae Howard, 1892 [Trjapitzin, 1973]. Now the senior author includes in this subtribe, besides Chrysoplatycerus, the following genera: Zarhopalus Ashmead, 1900 (New World), Ceraptrocerella Girault, 1918 (Australia), Zaplatycerus Timberlake, 1925 (Neotropical region), Tropidophryne Compere, 1931 (Afrotropical region), Hambletonia Compere, 1936 (Neotropical region), Neoplatycerus Subba Rao, 1965 (Egypt, Israel, India, Malaysia, Australia), Cryptoplatycerus Trjapitzin, 1982 (Costa Rica, Ecuador, Paraguay), Avernes Noyes and Woolley, 1994 (Canada, USA, Mexico, Costa Rica), Extencyrtus Noyes and Woolley, 1994 (USA), Manmohanencyrtus Singh, 1995 (India), Amasyxia Noyes, 2000 (Costa Rica), Peneax Noyes, 2000 (Costa Rica), Gavria Noyes, 2000 (Costa Rica), and Hipponactis Noyes, 2000 (Costa Rica). Another subtribe of Chrysoplatycerini is Taftiina Trjapitzin, 1973, which contains the genera Taftia Ashmead, 1904 (Malaysia, Indonesia, Philippines), Ananusia Girault, 1917 (Australia including Tasmania), Lutherisca Ghesquière, 1946 (Singapore), and Tshudo Trjapitzin, 2002 (distribution unknown, possibly Australasia). The senior author is currently preparing a review of Taftiina, where he hopes to elucidate its relationships with Chrysoplatycerina. Recently Hayat [2006] synonymized the tribe Chrysoplatycerini under Aenasiini Kerrich, 1967. Probably that is correct but the problem requires a more fundamental investigation. Depending on the systematic concept (evolutionary versus cladistic), the results may be different. The question is beyond the scope of this contribution, so we tentatively retain the tribal status of Chrysoplatycerini as valid.

In the subtribe Chrysoplatycerina only five genera possess 2-segmented antennal clava in the female, viz. Chrysoplatycerus, Cryptoplatycerus, Avernes, Amasyxia, and Peneax. Cryptoplatycerus has a linear antennal scape and two teeth at apex of mandible whereas the other genera have three such teeth. Avernes differs from other genera of this group by the presence of a deep incision at apex of the submarginal vein on the anterior margin of the fore wing. In Peneax, the antennal funicle is not broadened, and the stigmal vein of the fore wing is very short. Chrysoplatycerus and Amasyxia seem to be closely related as they have the following synapomorphies [Noyes, 2000]: scape and funicle of antenna strongly broadened and flattened, dorsal side of scape and pedicel flattened, facial scrobes with dorsal and lateral margins strongly carinate; mandible with the middle tooth notably the longest; fore wing with stigmal vein long and curved. Amasyxia can be distin- 


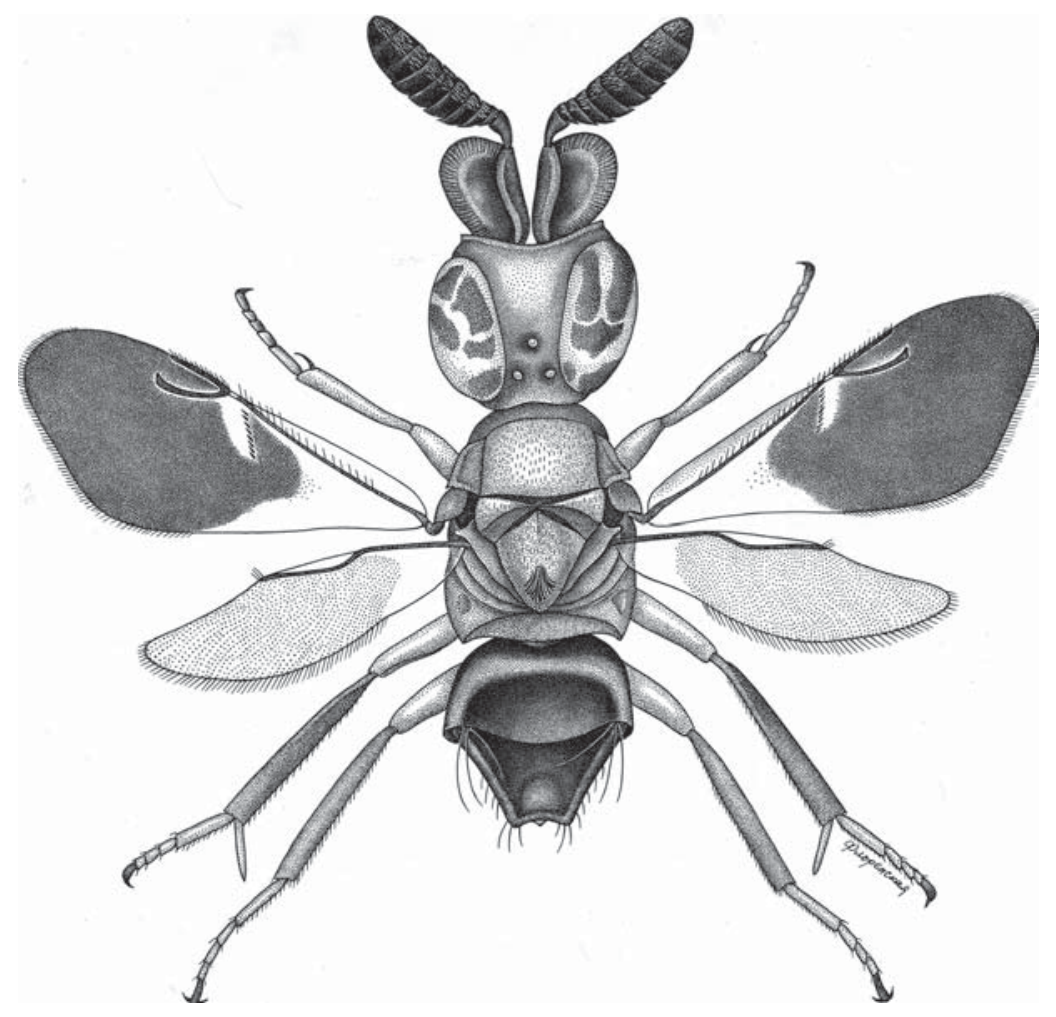

Fig. 1. Chrysoplatycerus ferrisi, female habitus (Riverside, California, USA; drawing by N.A. Florenskaya). Рис. 1. Chrysoplatycerus ferrisi, габитус самки (Riverside, California, USA; рисунок Н.А. Флоренской).

guished from Chrysoplatycerus mainly by the presence of dense setae in the apical half of the costal cell of the fore wing, a closed linea calva, and a strongly sculptured scutellum. These minor differences are hardly of generic value, and hence Amasixia might eventually be proven to be a junior subjective synonym of Chrysoplatycerus, but we abstain here from formally synonymizing the former under the latter genus because we do not have specimens of Amasyxia at our disposal for proper examination.

\section{Key to SPECIEs of ChrysoplatyCERUs (FEMALES)}

1(2) Scutellum without a compact tuft of long hairs at apex (at most with several strong, long setae); median longitudinal scutellar keel well developed, complete. Length of body $1.1-1.8 \mathrm{~mm}$ 3. Ch. flavicollis

2(1)Scutellum with a compact tuft of long hairs at apex (Fig. 1); median longitudinal scutellar keel absent or only weakly developed in the anterior part of scutellum.

3(4) Scutellum convex, with reticulate sculpture and with thin longitudinal median keel in the anterior part. Length of body $1.51-1.87 \mathrm{~mm}$ 2. Ch. ferrisi

4(3) Scutellum flat, smooth and shining, without longitudinal median keel.

5(6)Antenna with pedicel not flattened dorsally, small; funicle only moderately dilated, its segments not more than 2.0 times as wide as long. (Length of body was not indicated in the original description)

1. Ch. colombiensis
6(5)Antenna with pedicel flattened dorsally, not small; funicle strongly dilated, its segments 3.0-6.0 times as wide as long.

7(8) Head and mesosoma generally metallic green or blue, with pronotum and sometimes mesopleura mostly orange. Length of body $1.55-2.39 \mathrm{~mm}$.. 6. Ch. splendens

8 (7) Head and mesosoma generally ferruginous or orange.

9(10) Gaster blue-black. Head and mesosoma ferruginous. Hind legs brown, with tibiae dark and tarsi (except basal and apical tarsomeres) white or whitish. Length of body $1.2-1.9 \mathrm{~mm}$ 4. Ch. howardii

10(9)Gaster pale orange, basally brownish. Head and mesosoma mostly orange. Hind coxae whitish; femora, tibiae and tarsi orange. Length of body $1.45-1.66 \mathrm{~mm}$...... 5. Ch. ixion

\section{Synopsis of species}

1. Chrysoplatycerus colombiensis Kerrich, 1978

Kerrich, 1978: 139; Singh, 1995: 166.

DISTRIBUTION. Colombia (in banana debris). Biology unknown.

2. Chrysoplatycerus ferrisi Timberlake, 1922 Figs 1-4.

Timberlake, 1922: 4; Peck, 1963: 448; Kerrich, 1978: 137; Trjapitzin and Gordh, 1978: 405 (Metaplatycerus); Gordh and Trjapitzin, 1979: 106 (Metaplatycerus); Noyes, 1980: 185; Singh, 1995: 166; Noyes et al., 1997: 196. 

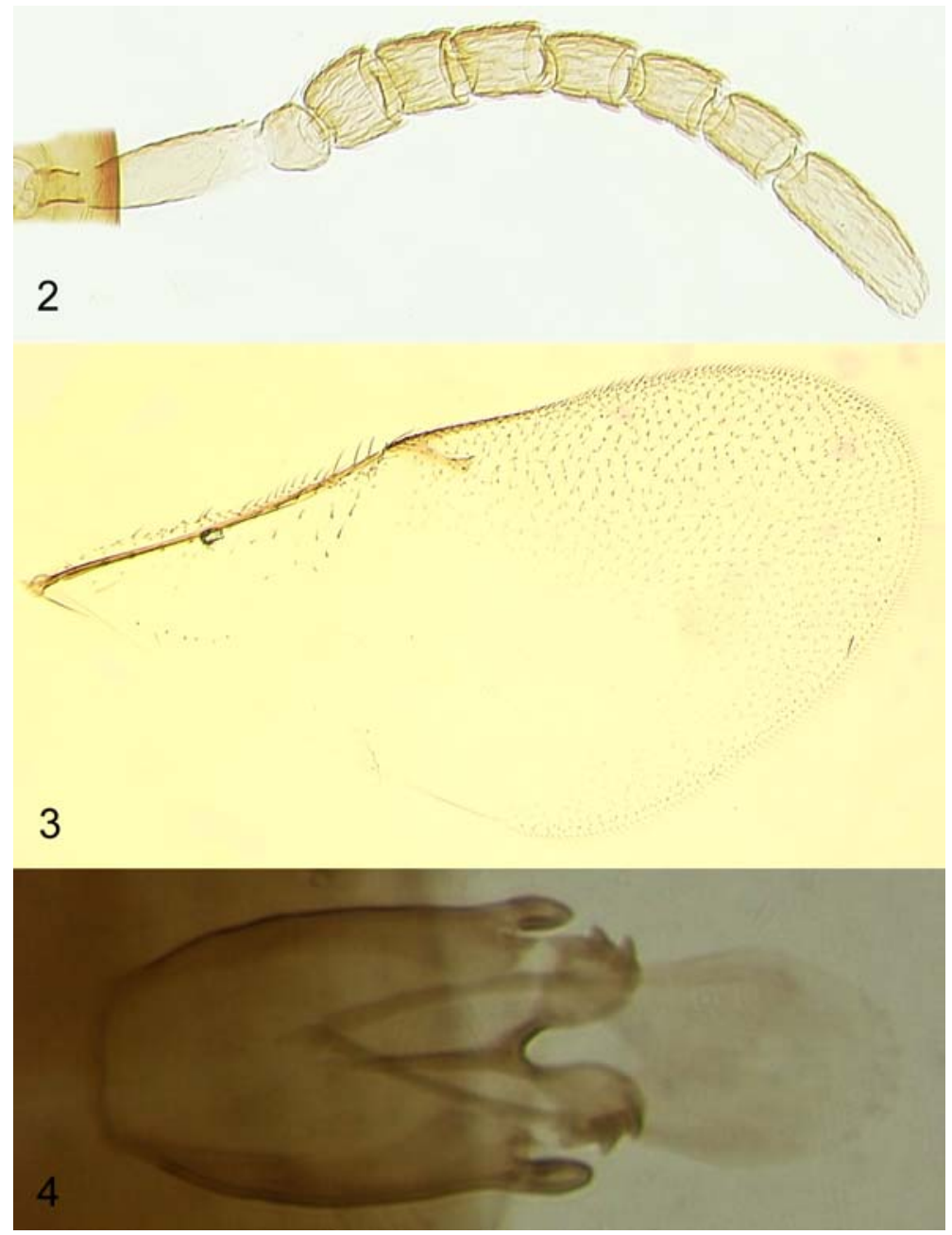

Figs 2-4. Chrysoplatycerus ferrisi, $\mathrm{O}^{\top}: 2$ - antenna (paratype); 3 - fore wing (paratype); 4 - genitalia (Riverside, California, USA). Рис. 2-4. Chrysoplatycerus ferrisi, O’: 2 - усик (паратип); 3 - переднее крыло (паратип); 4 - гениталии (Riverside, California, USA).

DISTRIBUTION AND BIOLOGY. USA (California), from chamise mealybug Anisococcus adenostomae (Ferris, 1925), probably on Adenostoma sp. (Rosaceae), a thorny chaparral plant, and also from Mexican mealybug Phenacoccus gossypii Townsend and Cockerell, 1898. According to Maple [1947], egg of Ch. ferrisi is devoid of an aeroscopic plate, and its larva is apneustic.

MATERIAL EXAMINED. TYPE MATERIAL. USA, California, San Diego Co., near San Diego, 10.ix.1920, G.F. Ferris, "Ex Pseudococcus adenostomae" ( $19,1 \sigma^{T}$ paratypes on points and 1 , $1 \mathrm{O}^{\mathrm{x}}$ paratypes on slides, UCRC)

NON-TYPE MATERIAL. USA. California: Los Angeles Co., Whittier, 6.iii.1935, J.D. Maple (ex. Phenacoccus gossypii) (11 females, UCRC). Riverside Co., Ca. $10 \mathrm{~km} \mathrm{~N}$ of Aguanga, $33^{\circ} 32^{\prime} 30^{\prime \prime} \mathrm{N} 116^{\circ} 52^{\prime} 30^{\prime \prime} \mathrm{W}, 905 \mathrm{~m}, 1 . i x .1978$ (1 ㅇ, UCRC). Gavilan Hills (SE of Lake Mathews, near Gavilan Peak), 9.vi.1950, P.H. Timberlake (on Eriogonum fasciculatum) (1 9 , UCRC). Menifee Valley (Hills at West end), $33^{\circ} 39^{\prime} \mathrm{N} 117^{\circ} 13^{\prime} \mathrm{W}$, J.D. Pinto, 18.v.1980 (1 +, UCRC); 4-8.vi.1981 ("pan trap under Adenostoma") (1 o, UCRC). Riverside, 24.xi.1933, S.E. Flanders ("Ex mealybug on Eriogonum Citrus Exp. Station") (1 , UCRC); 6.vii.1935, J.D. Maple (ex. Ph. gossypii in insectary) (3 우, $8 \bigcirc^{\top} \sigma^{7}$, UCRC); vii.1935, J.D. Maple (ex. Ph. gossypii) (1
ㅇ, FSCA; 11 우, 7 Oొం $^{\top}$, UCRC; 1 ㅇ, ZIN). San Diego Co., San Diego, ix.1920, H.M. Armitage ("Ex. mealy-bugs on greasewood") (2 9 , UCRC)

NOTE. Male of this species was described by Timberlake [1922]. Its antennal scape is smoothly convex ventrally and about 2.5 times as long as wide, and its body length is $0.84-1.18 \mathrm{~mm}$. The male antenna (Fig. 2) of $C h$. ferrisi has the flagellar segments relatively more elongate than those in Ch. splendens (Fig. 7) although their length and width may vary somewhat; it is thus possible that Timberlake [1922: 9, his Fig. 2] illustrated the male antenna of the latter species as that of $C h$. ferrisi: he did not make a slide mount of a male paratype of his species, it was made later (probably in the 1980s). Also illustrated here are the fore wing (Fig. 3 ) and the genitalia (Fig. 4) of the male of Ch. ferrisi.

\section{Chrysoplatycerus flavicollis (De Santis, 1972)}

Paraplatycerus citriculus Hall, 1974: 19 (synonymized by Kerrich, 1978: 138.).

De Santis, 1972: 49 (Encyrtolophus); Kerrich, 1978: 138; Singh, 1995: 166; Noyes, 2000: 215. 
DISTRIBUTION AND BIOLOGY. Argentina, Brazil, Guyana (new record), and Paraguay. This species was indicated by Hall [1974] as a parasitoid of Pseudococcus citriculus Green, 1922 (= Pseudococcus cryptus Hempel) on citrus. It was introduced from Paraguay into the USA, where, in California, this parasitoid was successfully mass-produced for intended release against the Comstock mealybug [Hall, 1974]. According to Jack Hall (personal communication), "the culture died out before the releases were made"; also see Meyerdirk and Newell [1979].

MATERIAL EXAMINED. TYPE MATERIAL. Paraplatycerus citriculus Hall: Paraguay, Asunción, M. Rose ("Ex. Pseudococcus citriculus on citrus"), 24.1973 [University of California, Riverside (UCR) Quarantine S\&R (Shipping \& Receiving) \#73-24] (1 9 paratype on point, UCRC); 5.ii.1973 [UCR Quarantine S\&R \#73-25, 1 o and $1 \sigma^{7}$ without paratype labels likely labeled erroneously as S\&R \#73-24] (1 9,1 O on points not marked as paratypes and $2 O^{7} O^{7}$ paratypes on points, UCRC); 9.ii.1973 [UCR Quarantine S\&R \#73-26] (1,$+ 10^{7}$ paratypes on slide and $1 \sigma^{\prime}$ paratype on point, UCRC).

Note that the collection dates of the entire paratype series are different from the single date given in the original description by Hall [1974], obviously by mistake because there were no shipments received in UCR Quarantine from Paraguay during 1972, for the type series of Paraplatycerus citriculus (9.ii.1972). Also, the dates on the specimens differ slightly from the ones given in the respective UCR Quarantine S\&R records: in fact, the only quarantine record that mentioned the consigned P. citriculus was S\&R \#73-20-B (the collection and shipping date indicated was 25.i.1973, the receiving date was 31.i.1973, and the host was then misidentified as Pseudococcus comstocki). The collection was made by M. Rose in Asunción on street citrus trees.

NON-TYPE MATERIAL. Guyana, iii.1956, F.D. Bennett ("adult captured on wild shrub") ( 1 , FSCA).

NOTE. The antennal scape of the male of Ch. flavicollis is similar to that of Ch. ferrisi.

4. Chrysoplatycerus howardii Ashmead, 1900, stat.rev.

Ashmead, 1900: 405; Timberlake, 1922: 5; Peck, 1963: 448; Browning, 1994: 34

DISTRIBUTION, BIOLOGY AND TAXONOMIC NOTES. This species was briefly described by Ashmead [1900] from two female specimens from ANSP, labeled: "461" and "435", which supposedly had been received from Mexico. One of the syntypes was deposited, according to him, in USNM (under Catalog No. 4764 but that was an error: the correct Catalog No. is 4765), and the other in ANSP. Timberlake [1922] wrote that A.B. Gahan informed him that he had examined the types of Ch. howardii in USNM and found that in regard to all the structural characters they were virtually identical with Ch. splendens (Howard, 1888). Nevertheless, Timberlake retained $C h$. howardii as a valid species in his key. Kerrich [1978] synonymized Ch. howardii under Ch. splendens, but he did not see the syntypes of the former species, and his conclusion was based only on one specimen from Florida, USA, determined as such by B.D. Burks. Kerrich, however, erroneously called the syntype of $C h$. howardii under the USNM Catalog No. 4765 as the holotype [Kerrich,
1978: 140], but that did not constitute a valid lectotype designation because the species was originally described from more than one specimen [Article 74.5: ICZN, 1999]. The junior author has examined that syntype specimen of Ch. howardii in USNM and labeled it accordingly as the lectotype that we designate here. The whereabouts of the paralectotype female (under the original No. 435) of Ch. howardii is unknown; it is not present either in ANSP (Jason Weintraub, personal communication) or in USNM (Terry Nuhn, personal communication); the junior author also could not find it during a visit to ANSP in April 2011.

Browning [1994] reported Ch. howardii as a valid species reared in Florida from the citrus mealybug Planococcus citri (Risso, 1813).

We hesitantly disagree with the synonymy proposed by Kerrich [1978] without a study of the type specimens and tentatively reinstate $C h$. howardii as a valid species based on examination of the lectotype in USNM, which unfortunately is incomplete (it lacks the head and both antennae). The distinctive ferruginous color of the mesosoma in the female of Ch. howardii (the color is somewhat similar to that in Ch. ferrisi) makes it unlikely that this species would be conspecific with $C h$. splendens in which it is consistently much darker although possibly that may be subject of intraspecific variability within the latter species. The scutellum in the lectotype of Ch. howardii is smooth and shining like in Ch. splendens.

MATERIAL EXAMINED. TYPE MATERIAL. Lectotype: female (on point, USNM), here designated to clarify the existing ambiguity about the status of the type specimens of this species, labeled: 1. “461.”; 2. “A. E. S. Coll.”; 3. [red] "Type No. 4765 U.S.N.M.”; 4. "Chrysoplatycerus bowardii Ashm. O"; 5. [red] "LECTOTYPE + Chrysoplatycerus howardii Ashmead, 1900 Designated by V.A. Trjapitzin and S.V. Triapitsyn; labeled by S.V. Triapitsyn 2011".

NON-TYPE MATERIAL. USA. Florida: Orange Co., Zellwood, 27.vii.1954, ex. Pseudococcus sp. (1 9 , USNM) (det. by B. D. Burks). Palm Beach Co., Lake Worth ("on AIA 1 mi. S. of 802"), 6.v.1973, W.H. Pierce, "associated with Lantana" (1 female, FSCA) (det. by E.E. Grissell). St. Lucie Co., Fort Pierce, 5.v.1953, H. Holtsberg, "ex Mealybug" (1 +, USNM) (det. by B.D. Burks). Also $1 \mathrm{O}^{7}$ (USNM) that may or may not belong to this species: USA, Florida, Polk Co., Auburndale, 12.vi.1952, M.H. Muma, ex. Planococcus citri (Risso, 1813).

\section{Chrysoplatycerus ixion Noyes, 2000}

Noyes, 2000: 217.

DISTRIBUTION. Mexico (Nayarit), Costa Rica.

\section{Chrysoplatycerus splendens (Howard, 1888)} Figs 5-9.

Howard in Smith, 1888: 80 (Rileya); Howard, 1888: 192 (Rileya); Ashmead, 1889: 38; Ashmead, 1900: 405; Essig, 1911: 520; Timberlake, 1922: 4; Essig, 1926: 819, 840; Peck, 1963: 448; Beardsley, 1976: 206; Bartlett, 1978: 157, 166; Kerrich, 1978: 140; Prinsloo, 1981: 101; Singh, 1995: 166; Noyes, 2000: 215; Daane et al., 2008: 173 (Chrysoplatycerus sp.).

DISTRIBUTION. USA [California, Florida (selfintroduced with the host), ?Texas (introduced into greenhouses with unknown results)], Mexico (Baja Califor- 

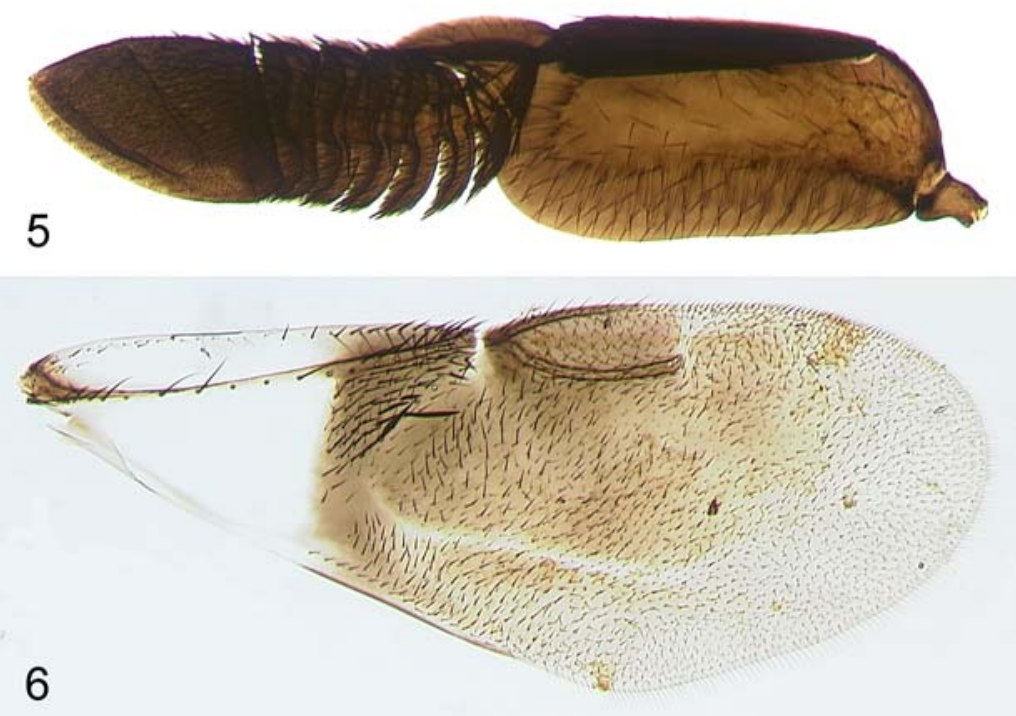

Figs 5, 6. Chrysoplatycerus splendens, female (Coronado Beach, California, USA): 5 - antenna; 6 - fore wing. Рис. 5, 6. Chrysoplatycerus splendens, самка (Coronado Beach, California, USA): 5 - усик; 6 - переднее крыло.

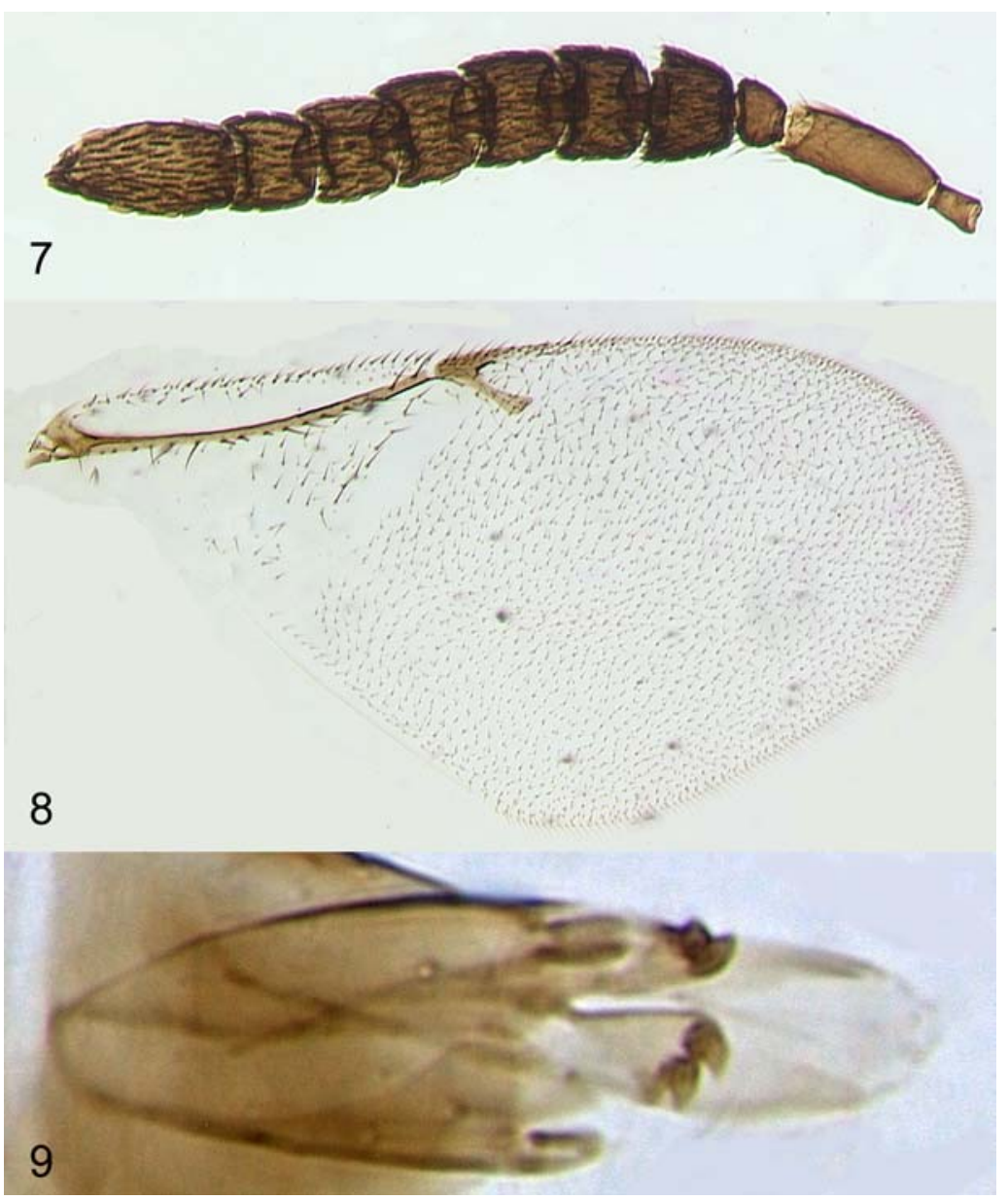

Figs 7-9. Chrysoplatycerus splendens, male: 7 - antenna (Pasadena, California, USA); 8 - fore wing (Pasadena); 9 - genitalia (Santa Ana, California, USA).

Рис. 7-9. Chrysoplatycerus splendens, самец: 7 - усик (Pasadena, California, USA); 8 - переднее крыло (Pasadena); 9 гениталии (Santa Ana, California, USA). 
nia Sur, Colima, Sinaloa), Costa Rica, Panama, Trinidad and Tobago, Hawaiian Islands (USA) (an accidental introduction), ?Ghana (introduced with unknown results), South Africa (successfully introduced and established), Italy (an accidental introduction).

MATERIAL EXAMINED. TYPE MATERIAL. Two paralectotype females, here designated and labeled accordingly (ANSP), of which only heads and antennae remain, mounted on separate, heavily crystallized, minuten pins embedded in a balsa wood piece on a pin labeled: "Rileya splendens Howard Type.". The mount is consistent with that of the lectotype and other paralectotypes as specified by Kerrich (1978: 141).

NON-TYPE MATERIAL. Mexico: Baja California Sur, Las Barracas (ca. $30 \mathrm{~km} \mathrm{E}$ of Santiago), $23^{\circ} 28^{\prime} 20^{\prime \prime} \mathrm{N} 109^{\circ} 27^{\prime} 10^{\prime \prime} \mathrm{W}, \mathrm{P}$. DeBach: 27.iv.1985 (1 +, UCRC); 17.v.1985 (1 9 , UCRC). Colima, Manzanillo, 25.iv.1980, F.D. Bennett, ex. Phenacoccus sp. on Acalypha sp. (1 +, FSCA). Sinaloa, 12 mi. N of Mazatlán, 25.x.1982, J.T. Huber (1 9,1 $\sigma^{7}$, UCRC). USA, California: Contra Costa Co., Kensington, $37^{\circ} 54^{\prime} 26^{\prime \prime} \mathrm{N} 122^{\circ} 16^{\prime} 32^{\prime \prime} \mathrm{W}$ 31.viii.1995, H.A. Daly (1 + EMEC). Los Angeles Co.: Los Angeles, 9.xii.1955, R.X. Schick (1 o, UCRC). Pasadena: 13.viii.1911, P.H. Timberlake, ex. Dysmicoccus ryani (Coquillett, 1889) (1 +, UCRC); 19.viii.1912, P.H. Timberlake (ex. D. ryani on cypress) (1 9 , UCRC); 29.vii.1915, E.J. Branigan (ex. Pseudococcus sp. on algaroba) (1 o', UCRC). San Pedro, 8-16.xi.2001, J. George (1 +, UCRC). Whittier, ii.1922, H. Compere ("lab. culture") (2 Oo, 1 \% , UCRC); "State Insectary Calif. 2001" (likely in Whittier) (10 우, UCRC). Orange Co.: Anaheim, 18.ix.1950, B.R. Bartlett, ex. Pseudococcus longispinus (Targioni Tozzetti, 1867) (5 우, 5 ○ $\sigma^{7}$, UCRC). Laguna Canyon, 12.vii.1983, H. Andersen (2 우, UCRC). Santa Ana, P. DeBach: 23.x.1945 (1 +. UCRC); 5-6.xi.1945 (ex. Pseudococcus sp. on orange) (1 o, 1 o , UCRC); collected 24.i.1946, emerged 28.ii.1946 (ex. P. Longispinus on orange) (1 +, UCRC). Santa Ana Mountains, San Juan Creek at San Juan Fire Station, 10.ix.1997, M. Gates (1 +, UCRC). Tustin, 16.vii.1937, J.D. Maple (ex. Pseudococcus maritimus Ehrhorn, 1900) (1 +, UCRC) Riverside Co., Riverside: White Park, 30.viii.1914, C.P. Clausen (2 우, UCRC); 30.vii.1924, H. Compere (ex. P. maritimus) (1 9 , UCRC); 4.viii.1924, H. Compere (ex. P. maritimus) (2 $0^{7} \sigma^{7}$ UCRC); x.1924, C.P. Clausen (1 o, UCRC); 28.i.1934, H. Compere (ex. P. maritimus) (1 +, UCRC); H. Compere (ex. P. maritimus) (1 +, UCRC); 4.viii.1951, P.H. Timberlake (at light) (1 + , UCRC); 22.iii.1961, J. Bell (1 +, UCRC); 2.vii.1978, J.B. Woolley (on apricot) (1 9 , UCRC); UCR campus, 27-30.ix.1981, JT. Huber (1 9 , UCRC); UCR campus, 17 xii.1981-2.i1982, JT. Huber (1 , UCRC). San Diego Co.: Batiquitos Lagoon (1 mi. E of Leucadia), 8.viii.1979, C. Melton (7 오, 1 ○', UCRC) Coronado Beach, P.H. Timberlake, 20.ix.1912 (ex. P. Longispinus on Ceratonia siliqua Linnaeus, 1753) (1 +. UCRC); 27.ix.1912 (ex. Pseudococcus sp. on algaroba) (1 9 , UCRC). Rancho Santa Fe, 8.viii.1979, G. Gordh (1 9 , UCRC); 8.viii.1979, C. Melton (5 우, 1 O$^{7}$, UCRC). San Diego: 28.viii.1929, H. Compere (ex. P. maritimus on Passiflora sp.) (1 ㅇ, FSCA; 2 오, $10^{7}$, UCRC) Pacific Beach, 29.viii.1929, H. Compere, S.E. Flanders (ex. P. maritimus on Passiflora sp.) (1 9 , UCRC). San Onofre Bluff, $33^{\circ}$ $21^{\prime} 38^{\prime \prime} \mathrm{N} 117^{\circ} 32^{\prime} 22^{\prime \prime} \mathrm{W}$, 4.ix.1999, D. Yanega, M. Gates (1 UCRC). San Onofre State Beach, 19.vi.1996, D.C. Hawks (1 UCRC). Santa Barbara Co.: Santa Barbara, 3.xii.1921, I. French (1 9 , UCRC). Winchester Canyon, 16.v.1965, J.C. Hall (on Salix sp.) (1 o, EMEC). Tulare Co., Ducor, Ave. 56 at Rd. 152, 4.x.2005, D. Haviland (ex. Ferrisia gilli Gullan, 2003 on persimmon) (1 O', UCRC). Ventura Co.: Camarillo, 5.ix.1956, C.F. Lagace, ex. Planococcus citri (Risso, 1813) (3 $0^{7} \sigma^{7}$, UCRC) Santa Paula, v.1910, E.O. Essig (3 우, UCRC); E.O. Essig (12 females, $10^{7}$, UCRC); no other data (2 +9 , UCRC); 16.viii.1956, C.F. Lagace ( $30^{7} \sigma^{7}$, UCRC). Florida, Palm Beach Co., Palm Beach, 6.ix.1977, "sticky trap" (1 ㅇ, FSCA) (det. by E.E. Grissell)

TAXONOMIC NOTES. Female. Provided are for the recognition of this species the digital photographs of its antenna (Fig. 5) and the fore wing (Fig. 6).
Male. Body length 1.03-1.29 mm. Antenna (Fig. 7) with funicle segments transverse or subquadrate. Fore wing as in Fig. 8; genitalia as in Fig. 9.

Immature stages. These were studied by Maple [1947]; the egg of Ch. splendens is unbanded (without an aeroscopic plate), and the larva is apneustic.

BIOLOGY AND COMMENTS. This economically important species was collected for the first time in Los Angeles, Califorrnia, USA by Albert Koebele, pioneer of biological control of insect plant pests, in the third quarter of the 19th Century. The host of the parasitoid was an undetermined mealybug on passion-flower vine (Passiflora sp.). Essig [1911, 1926] discovered that in California Ch. splendens parasitizes Planococcus citri (Risso, 1813), an accidentally imported mealybug pest of citrus, and also found that it attacks the indigenous species Pseudococcus maritimus Ehrhorn, 1900. He suggested that $C h$. splendens might had been introduced into California from the Philippines; however, Noyes [2000] stated that such an introduction was unlikely and that it is more probable that the parasitoid in the Philippines could belong to the genus Taftia Ashmead, 1904, species of which occur there and have a similar general appearance to those of Chrysoplatycerus.

Clausen [1924] investigated the parasitoids of $P$. maritimus in California intermittently from 1915 to 1920. His surveys were carried out in three areas of the state: 1) southern California, on citrus, where Ch. splendens was then common; 2) the Central Valley, where it was one of the effective parasitoids of $P$. maritimus of grapes; in the San Joaquin Valley this mealybug did not live on citrus trees growing immediately adjacent to the heavily infested vines; 3 ) the San Francisco Bay area of northern California, where $P$. maritimus was a serious pest in pear orchards; Ch. splendens was not found there by Clausen. Nevertheless, it occurs in the Sacramento Valley [Clausen, 1924] and also in Contra Costa County in northern California (see "Material examined").

So which species of mealybugs are the native hosts of Ch. splendens in California? Most probably, the main host is $P$. maritimus - the native species to California well adapted to the different climatic conditions and plant hosts.

Besides California in the USA, Ch. splendens was found in Baja California Sur (Las Barracas is near the coast), which is arguably within the Neotropical part of Mexico, and also in Colima (see "Material examined"). Earlier, Pérez-Pérez et al. [1999] recorded it from the Mexican State of Sinaloa. Supposedly, the Pacific subtropical region of North America could be regarded as the native range of $C h$. splendens. The question whether it is indigenous also to Costa Rica, Panama, and Trinidad and Tobago is not clear and needs investigation. However, taking into consideration that in Costa Rica the species is widely distributed in the native wild forests, and in Trinidad Island it was found on the edge of a mangrove swamp, we assume that in these tropical habitats it is also apparently autochthonous. Recently 
Ch. splendens was discovered in Italy (Veneto), where it was reared from Pseudococcus comstocki (Kuwana, 1902) on Viburnum tinus Linnaeus, 1753 [Guerrieri, Pellizzari, 2009]. That was the first record of Ch. splendens from Europe, although only one female was collected during two years of surveys.

One female in FSCA [Cayman Islands (UK), Grand Cayman Island, 14.vi.1986, F.D. Bennett, "ex. mealybug on Pluchea"] may or may not belong to this species as it has a somewhat intermediate body color between $C h$. splendens and $C h$. howardii yet is more similar to the former.

Ch. splendens was used in four classical biological control programs, as follows.

1. Introduction from California into the Republic of South Africa, beginning in 1933, against P. maritimus, a troublesome pest of grapes and pear. The parasitoid was mass-reared, and the total of 6290 wasps were released at two sites between 1934 and 1940. In 1940 and 1942 large numbers of this encyrtid emerged from Pseudococcus viburni (Signoret, 1875) on the infested pears [Joubert, 1943; Greathead, 1971]. According to Prinsloo [1981], in South Africa it parasitizes the mealybugs $P$. viburni on Acacia cyclops Don, 1832 and Planococcus ficus (Signoret, 1875) on grapes; it has been well established in Western Cape Province but during the past 40 years has appeared to be rare and was collected only twice.

2. Introduction from California into Ghana for biological control of Planococcoides njalensis (Laing, 1929), a vector of cacao swollen shoot virus on cacao tree Theobroma cacao Linnaeus, 1753, but results of its release remain unknown [Greathead, 1971; Bartlett, 1978].

3. Introduction into greenhouses in Canada (Ontario and Quebec) for the control of P. maritimus [Baird, 1940; McLeod, 1962; Peck, 1963]. In 1939, Zarhopalus corvinus (Girault, 1915) and Ch. splendens were obtained from California and propagated in Belleville, Ontario; the parasitoids used in Canada were collected from a host strain almost certainly different from that in the Canadian greenhouses. This project was a failure [Turnbull, Chant, 1961].

4. Introduction into greenhouses in Texas, USA against Planococcus citri on citrus [Summy et al., 1986]. The results are unknown.

It was proposed [Trjapitzin, 1963, 1981; Tryapitsyn, 1966] to introduce $C h$. splendens from California into the USSR against $P$. maritimus, which caused damage to many subtropical cultivated plants, especially to tung oil trees Aleurites fordii (Hemsley, 1906) and A. cordata (Thunberg, 1783) (Euphorbiaceae) on the Black Sea coast of the Caucasus. However, the idea has not been materialized.

\section{Chrysoplatycerus sp. (not included in the key)}

López Pérez, 2003: 127.

DISTRIBUTION. Cuba. Biology unknown.

\section{ACKNOWLEDGEMENTS}

The senior author thanks Robert L. Zuparko for the possibility to study the collections of the EMEC, Natalia A. Florenskaya (St. Petersburg, Russia) for an artistic drawing of Ch. ferrisi, and Elizaveta Ya. Shuvakhina (Moscow, Russia) for critically reading the earlier draft of the manuscript and also for valuable advice. The junior author is acknowledging Terry Nuhn (USNM) and Jim Wiley (FSCA) for arranging loans of specimens from the respective collections.

\section{References}

Ashmead W.H. 1888. The chalcid genus Rileya // The Canadian Entomologist. Vol.20. No.12. P.229-230.

Ashmead W.H. 1889. A final word about the genus Rileya // The Canadian Entomologist. Vol.21. No.1. P.37-38.

Ashmead W.H. 1900. On the genera of chalcid-flies belonging to subfamily Encyrtinae // Proceedings of the United States National Museum. Vol.22. No.1202. P.323-412.

Baird A.B. 1940. Summary of insect parasites and predators liberated in Canada and Newfoundland 1939 // Canadian Insect Pest Review. Vol.18. P.94-126.

Bartlett B.R. 1978. Pseudococcidae // Clausen C.P. (ed.). Introduced parasites and predators of arthropod pests and weeds: a world review. United States Department of Agriculture, Agricultural Research Service, Agriculture Handbook No.480. Washington, D.C. P.137-140.

Beardsley J.W. 1976. A synopsis of the Encyrtidae of the Hawaiian Islands with keys to genera and species (Hymenoptera: Chalcidoidea) // Proceedings of the Hawaiian Entomological Society. Vol.22. No.2. P. 81-228.

Browning H.W. 1994. Classical biological control of citrus scale insects // Rosen D., Bennett F.D., Capinera J.L. (eds). Pest management in the subtropics. Biological control - a Florida perspective. Intercept, Andover, UK. P.49-78.

Clausen C.P. 1924. The parasites of Pseudococcus maritimus (Ehrhorn) in California (Hymenoptera, Chalcidoidea). Part II. Biological studies and life histories // University of California Publications. Technical Bulletins. Vol.3. No.2. P.253-288.

Daane K.M., Cooper M.L., Triapitsyn S.V., Walton V.M., Yokota G.Y., Haviland D.R., Bentley W.J., Godfrey K., Wunderlich L.R. 2008. Vineyard managers and researchers seek sustainable solutions for mealybugs, a changing pest complex // California Agriculture. Vol.62. No.4. P.167-173, 175.

De Santis L. 1972. Adiciones a la fauna argentina de encírtidos. III. (Hymenoptera: Chalcidoidea) // Revista Peruana de Entomología. Vol.15. No.1. P.44-60.

Essig E.O. 1911. The natural enemies of the citrus mealybug. IV. // Pomona College Journal of Entomology [California, USA]. Vol.3. P.518-522.

Essig E.O. 1926. Insects of western North America. New York. $1035 \mathrm{pp}$.

Gibson G.A.P. 1997. Chapter 2. Morphology and terminology // Gibson G.A.P., Huber J.T., Woolley J.B. (eds.). Annotated keys to the genera of Nearctic Chalcidoidea (Hymenoptera). Ottawa: NRC Research Press. P.16-44.

Gordh G., Trjapitzin V.A. 1979. [Review of genera of parasitic Hymenoptera of the tribe Chrysoplatycerini (Hymenoptera, Encyrtidae) with descriptions of a new myrmecophilous genus from Tasmania] // Trudy Zoologicheskogo Instituta Akademii Nauk SSSR. Vol.82. P.103-112 [in Russian].

Greathead D.J. 1971. A review of biological control in Ethiopian region // Technical Communications in the Commonwealth Institute of Biological Control. N.5. P.1-162.

Guerrieri E., Pellizzari G. 2009. Parasitoids of Pseudococcus comstocki in Italy. Clausenia purpurea and Chrysoplatycerus splendens: first records from Europe // Bulletin of Insectology. Vol.62. No.2. P.179-182. 
Hall J.C. 1974. A new genus and species of mealybug parasite from Paraguay (Hymenoptera: Encyrtidae) // Entomological News. Vol.85. No.1. P.19-21.

Hayat M. 2006. Indian Encyrtidae (Hymenoptera: Chalcidoidea) [Keys to genera and species, and a catalogue, with 1591 figures]. Aligarh: Privately published. i-viii+496 pp.

Howard L.O. 1888. The chalcid genus Rileya // The Canadian Entomologist. Vol.20. No.10. P.191-195.

Howard L.O. 1889. One word more about Rileya // The Canadian Entomologist. Vol.21. No.1. P.13-14.

[ICZN] International Commission on Zoological Nomenclature. 1999. International Code of Zoological Nomenclature. Fourth Edition adopted by the International Union of Biological Sciences // The International Trust for Zoological Nomenclature c/o The Natural History Museum, Cromwell Road, London. Padova: Tipografia La Garangola. I-XXIX + 306 pp.

Joubert C.J. 1943. The introduction into the Union of South Africa of some natural enemies of mealy bugs. // The Journal of the Entomological Society of Southern Africa. Vol.6. P.131-136.

Kerrich C.J. 1978. A revision of dinocarsiine Encyrtidae with a study of the genus Pelmatencyrtus De Santis (Hymenoptera: Chalcidoidea) // Zoological Journal of the Linnean Society. Vol.62. No.2. P.109-159.

López Pérez M. 2003. A preliminary list of the Encyrtidae (Hymenoptera: Chalcidoidea) of Cuba with descriptions of two new species // Journal of Hymenoptera Research. Vol.12. No.1. P.125-135.

Maple J.D. 1947. The eggs and first instar larvae of Encyrtidae and their morphological adaptations for respiration // University of California Publications in Entomology. Vol.8. No.2. P.iviii $+25-122$.

McLeod J.H. 1962. A review of the biological control attempts against insects and weeds in Canada. Part I. Biological contro of pests of crops, fruit trees, ornamentals, and weeds in Canada up to 1959 // Commonwealth Institute of Biological Control, Technical Communications [Ottawa, Canada]. No.2. P.1-33.

Meyerdirk D.F., Newell J.M. 1979. Importation, colonization and establishment of natural enemies of the Comstock mealybug in California // Journal of Economic Entomology. Vol.72. No.1. P.70-73.

Noyes J.S. 1980. A review of the genera of Neotropical Encyrtidae (Hymenoptera: Chalcidoidea) // Bulletin of the British Museum (Natural History). Entomology Series. Vol.41. No.3. P.107-253.

Noyes J.S. 2000. Encyrtidae of Costa Rica (Hymenoptera: Chalcidoidea), 1 . The subfamily Tetracneminae, parasitoids of mealybugs (Homoptera: Pseudococcidae) // Memoirs of the American Entomological Institute. Vol.62. P.1-355.

Noyes J.S., Woolley J.B., Zolnerowich G. 1997. Chapter 8. Encyrtidae // Gibson G.A.P., Huber J.T. \& Woolley J.B. (eds.). Annotated keys to the genera of Nearctic Chalcidoidea (Hymenoptera). Ottawa: NRC Research Press. P.170-320.

Peck O. 1963. A catalogue of the Nearctic Chalcidoidea (Insecta: Hymenoptera) // The Canadian Entomologist. Supplement No.30. P.1-1092.
Pérez-Pérez P., González-Hernández A., Nuñez-Cebrero R.D., Angulo-Bojorquez A. 1999. Determinación, distribución, abundancia relativa y diversidad de los encírtidos (Hymenoptera: Chalcidoidea) en el Valle de Culiacán, Sinaloa, México // Memorias XII Congreso Nacional de Control Biológico (Colegio de Postgraduados, Montecillo, Edo. de México, 28 y 29 de octubre de 1999). P.26-29.

Prinsloo G.L. 1981. Annotated records of economically important Chalcidoidea (Hymenoptera) from South Africa. II // Phytophylactica. Vol.13. No.2. P.101-103.

Singh S. 1995. Manmohanencyrtus, a new encyrtid genus from Andaman Islands, India and notes on the genus Chrysoplatycerus Ashmead (Hymenoptera: Chalcidoidea: Encyrtidae) // Oriental Insects. Vol.29. P.161-173.

Smith J.B. 1888. [Society News] Ento. Soc. Washington, June 7th, 1888 // Entomologica Americana. Vol.4. No.4. P.80.

Summy K.R., French J.V., Hart N.G. 1986. Citrus mealybug, Planococcus citri (Homoptera: Pseudococcidae), on greenhouse citrus. Density dependent regulation by an encyrtid parasite complex // Journal of Economic Entomology. Vol.79. P.891895.

Timberlake P.H. 1922. A revision of the chalcid-flies of the encyrtid genus Chrysoplatycerus // Proceedings of the United States National Museum. Vol.61. Art.2. No.2423. P.1-10.

Trjapitzin V.A. 1963. [A review of works on acclimatization of encyrtids for control of agricultural pests and suggestions for their acclimatization in the USSR] // Yanushevich A.J. (ed.). [Acclimatization of animals in the USSR]. [Proceedings of the Conference on Acclimatization of Animals in the USSR held in Frunze, 10-15 May 1963]. Alma-Ata: Edition of the Academy of Sciences of Kazakh SSR. P.328-331 [in Russian].

Trjapitzin V.A. 1973. [Classification of parasitic Hymenoptera of the family Encyrtidae (Chalcidoidea). Part I. Review of systems of classifications. The subfamily Tetracneminae Howard, 1892] // Entomologicheskoye Obozreniye. Vol.52. No.1. P.163-175 [in Russian].

Trjapitzin V.A. 1981. [Possibilities of introduction in the USSR of parasitic chalcids (Hymenoptera, Chalcidoidea) - natural enemies of agricultural pests] // Entomologicheskoye Obozreniye. Vol.60. No.3. P.484-493 [in Russian].

Trjapitzin V.A. 1989. [Parasitic Hymenoptera of the fam. Encyrtidae of Palaearctics] // Leningrad: Nauka. 488 pp. [in Russian].

Trjapitzin V.A., Gordh G. 1978. [A review of genera of Nearctic Encyrtidae (Hymenoptera, Chalcidoidea)] I // Entomologicheskoye Obozreniye. Vol.57. No.2. P.364-385 [in Russian].

Tryapitsyn [Trjapitzin] V.A. 1966. Survey of acclimatization of Encyrtidae for control of agricultural pests and suggestions for their acclimatization in the USSR // Israel Program for Scientific Translations. Jerusalem. P.226-229. [English translation of Trjapitzin, 1963]

Turnbull A.L., Chant D.A. 1961. The practice and theory of biological control of insects in Canada // Canadian Journal of Zoology. Vol.39. No.5. P.697-753. 